\title{
Gender Diversity on Board and Financial Reporting Quality in an Emerging Country
}

\author{
Wan Razazila Wan Abdullah, Enny Nurdin Sutan Maruhun, Norzarina \\ Noordin, Naimah Ahmad Yahya
}

To Link this Article: http://dx.doi.org/10.6007/IJARAFMS/v11-i3/11179 DOI:10.6007/IJARAFMS/v11-i3/11179

Received: 11 July 2021, Revised: 15 August 2021, Accepted: 29 August 2021

Published Online: 18 September 2021

In-Text Citation: (Abdullah et al., 2021)

To Cite this Article: Abdullah, W. R. W., Maruhun, E. N. S., Noordin, N., \& Yahya, N. A. (2021). Gender Diversity on Board and Financial Reporting Quality in an Emerging Country. International Journal of Academic Research in Accounting Finance and Management Sciences, 11(3), 586-600.

Copyright: (c) 2021 The Author(s)

Published by Human Resource Management Academic Research Society (www.hrmars.com)

This article is published under the Creative Commons Attribution (CC BY 4.0) license. Anyone may reproduce, distribute, translate and create derivative works of this article (for both commercial and non-commercial purposes), subject to full attribution to the original publication and authors. The full terms of this license may be seen at: http://creativecommons.org/licences/by/4.0/legalcode

Vol. 11, No. 3, 2021, Pg. 586 - 600

Full Terms \& Conditions of access and use can be found at http://hrmars.com/index.php/pages/detail/publication-ethics 


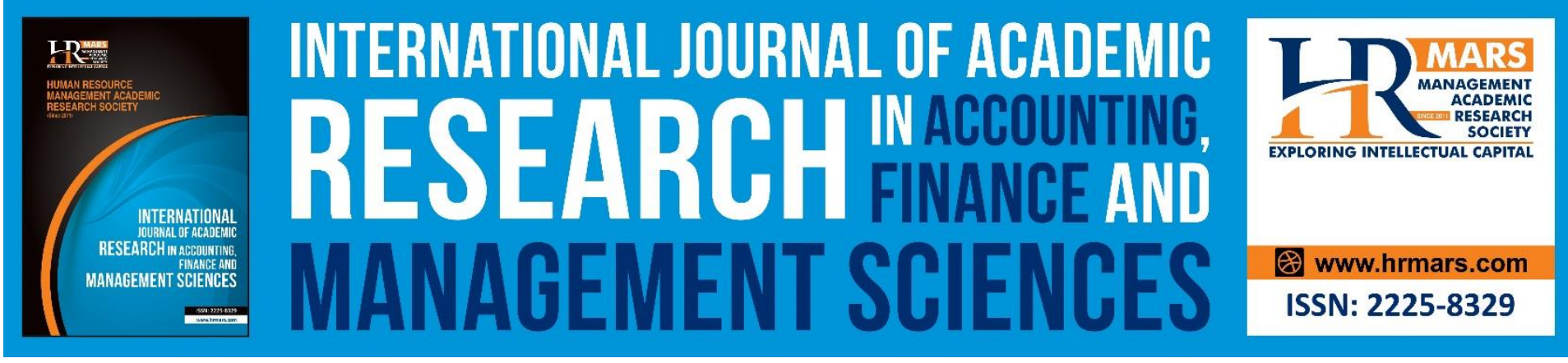

\title{
Gender Diversity on Board and Financial Reporting Quality in an Emerging Country
}

\author{
Wan Razazila Wan Abdullah, Enny Nurdin Sutan Maruhun, \\ Norzarina Noordin, Naimah Ahmad Yahya \\ Faculty of Accountancy, Universiti Teknologi MARA, Perak Branch, Tapah Campus, 35400, \\ Tapah Road, Perak, Malaysia \\ Corresponding Author: wanrazz@uitm.edu.my
}

\begin{abstract}
The board of directors' monitoring function derived from the agency theory plays a crucial role in mitigating agency problems and monitoring managerial decisions to protect shareholders' interests and to ensure high-quality financial reporting. There is a recent growing stream of research on the effects of gender differences that state that the presence of women on the board of directors could bring about positive outcomes in a firm's performance, corporate monitoring, and oversight. Thus, the purpose of this study is to investigate whether the gender diversity of the board of directors has a significant impact on the firm's financial reporting quality proxied by earnings management. This study employs panel data analysis of the financial data and qualitative data for the period from 2016 until the latest ones 2020 of Malaysian listed companies, as evidence from emerging countries. The empirical results of this study indicate that female directors on board mitigate earnings management. Thus, the results provide insights for regulators and policymakers; that the presence of female directors will affect management decisions and audit quality, therefore gender diversity on board should be further emphasized.
\end{abstract}

Keywords: Agency Theory, Corporate Governance, Earnings Quality, Earnings Management, Gender Diversity

\section{Introduction}

Good corporate governance is one of the most essential mechanisms in ensuring the achievement of goals and objectives of an organization, meeting shareholders' wealth, and preparing the quality of financial reporting. The role of corporate governance and financial reporting quality are amongst the most popular issues being investigated by researchers in the accounting field. The board of directors is a significant corporate governance mechanism that holds the accountability for leading and directing a business organization and protecting the interests of all stakeholders (Fama \& Jensen, 1983; Jensen \& Meckling, 2019). The board of directors become the key player for the corporation in ensuring effective corporate governance to reduce information asymmetry, control insiders' opportunism, and mitigate managerial incentives in earnings management practices and thus contribute to the integrity of the financial reporting (Chen et al., 2011; Chi et al., 2015; Khalil \& Ozkan, 2016; Peasnell et 
MANAGEMENT SCIENCES

Vol. 11, No. 3, 2021, E-ISSN: 2225-8329 @ 2021 HRMARS

al., 2005). The board of directors, thus, reduce the agency problem between agents (managers) and principals (shareholders) (Fama \& Jensen, 1983; Hillman \& Dalziel, 2003; Zahra \& Pearce, 1989)

Earnings management (EM) has been defined by Schipper (1989) as a purposeful intervention in the external financial reporting process, with the intent of obtaining some private gain. Meanwhile, Healy and Wahlen (1999) claimed that managers use judgment in financial reporting and in structuring transactions to alter financial reports to either mislead some stakeholders about the underlying economic performance of the company or to influence contractual outcomes that depend on reported accounting numbers. On top of that, Sun and Rath (2008), also define EM as managers exercising judgment to hide true performance to either influence the stock performance, to benefit from the contractual terms between the firm and managers, or to influence regulatory decisions. Therefore, based on previous literature, EM has been defined as where the managers may use the opportunity to show their firm's best performance through manipulation of the financial reporting. In mitigating $E M$, the board gender differences as one of the mechanisms have been established in many countries around the world. The presence of female directors on the corporate board may affect management decisions and financial decisions quality positively. Nevertheless, until this point in time, there is limited literature concerning the board gender differences in reducing EM activities in Malaysian capital market.

Consequently, the objective of this paper is to investigate the relationship between the presence of female directors on corporate boards that improves the audit quality of financial reporting among Malaysian public listed companies, particularly in the construction sector. Consistent with the prior studies, this paper uses accruals earnings management (AEM) as a proxy of earnings quality of financial reporting quality. From the year 2016 to the latest 2020, the study finds that the presence of female directors on board has a significantly negative relationship with EM. In addition to using the latest thus more relevant data, the study also expands further literature on the factors that will reduce EM which then improves the quality of the financial reports in an emerging market.

The remainder of the paper is organized as follows. Section 2 includes previous literature on gender diversity on corporate boards and EM and the development of research hypotheses. Section 3 elaborates the research design and data methodology. Section 4 presents and discussion on the findings and section 5.0 provides the summary and conclusion.

\section{Literature Review}

\section{Corporate Governance and Earnings Management}

Previous researches had proved to give understanding on the relationship between gender diversity and financial reporting quality (Gull et al., 2018, Al-Shaer \& Zaman, 2016, Triki Damak, 2018 Krishnan \& Parsons, 2008, Kyaw, Olugbode \& Petracci, 2015, Liu, Wei \& Xie, 2014; Adams \& Ferreira, 2009; Arun, Almahrog \& Aribi, 2015; Peni \& Vähämaa, 2010; Orazalin, 2020; Thiruvadi \& Huang, 2011; Kalantonis, Schoina \& Kallandranis, 2021). However, previous studies showed differing conclusions on the relationship between these two variables: it can be either positively correlated or negatively correlated and some studies show questionable results.

According to Gull et al (2018) and their study examine a sample of French firms on the relationship between female directors and EM and claimed that female directors deter EM. They found evidence that business expertise and audit committee membership are key attributes of female directors that promote the effective monitoring of EM. In addition, 
MANAGEMENT SCIENCES

Vol. 11, No. 3, 2021, E-ISSN: 2225-8329 @ 2021 HRMARS

Thiruvadi \& Huang (2011), their research in the United States provides evidence that the presence of a female director on the audit committee constraints EM by increasing negative (income-decreasing) discretionary accruals. They suggested that gender diversity on the board should be more emphasized as their presence may further enhance public confidence. Similarly, Orazalin (2020), in their study on public listed companies in Kazakhstan, found that companies with greater board gender diversity are more effective in constraining EM. Their findings also indicate that companies with larger boards adopt a more restrained approach to EM practices. However, the results provide weak evidence of the association between board independence and earnings quality. On top of that, Arun et al (2015) found that firms with a higher number of female and independent female directors are adopting restrained EM practices in the UK. They made a distinction between complex (high debt) and simple (low debt) companies, and the outcomes revealed that female directors have a positive effect on the EM in simple companies. Their findings suggest that female representation may enhance the functioning and efficiency of corporate boards and committees and, more generally, that executive gender may affect managerial behavior.

Another study by Peni \& Vähämaa (2010), the result of their empirical analysis using a sample of firms in the US, provides evidence that firms with female chief financial officers (CFOs) are associated with income-decreasing discretionary accruals, thereby implying that female CFOs are following more conservative EM strategies. They concluded that that female CFOs are following more conservative financial reporting strategies, which is broadly consistent with the literature on gender differences in conservatism and risk-aversion. Besides, Triki Damak (2018), found empirical results of a significant negative effect of board women presence on EM level in the French context. They, therefore, suggested that women on boards are effective in their monitoring role, which support the efforts made by French political bodies to increase gender diversity on corporate boards, and might inspire political actors of other countries to take initiatives to regulate the promotion of women's appointment on boards of directors. Using sample companies of European countries Saona et al (2019) and Kyaw et al., (2015) revealed the benefits of having a balanced board, in terms of gender diversity. They claimed that an equilibrated board tends to mitigate EM practices. Their analysis revealed that the regulatory framework regarding board gender diversity established by each country has a determinant role in reaching equality in decision-making positions, as a founding value of the European Union. On top of that, Albawwat and Harasees (2019) claimed that in their study, on commercial banks listed on the Amman Stock Exchange, there is a positive relationship between the presence of a female in the Audit Committee and the quality of the financial reports. Meanwhile, Darmayanti and Kassim (2020) asserted that female directors network had a positive relationship with earnings quality in public companies in Indonesia Stock Exchange 2015-2018 period.

On the other hand, contrary to the other literature, (Kalantonis et al., 2021) found no significant statistical evidence of the relationship between gender diversity and EM in Greek. According to Al-Shaer \& Zaman (2016), a diverse board will take a more balanced view and pay greater attention to social responsibility and stakeholder concerns. Based on their study on the UK context they found that gender-diverse boards are associated with higher quality sustainability reports and independent female directors have a greater effect on sustainability reporting quality than female directors. Meanwhile, Zainal, Zulkifli, and Salleh (2013) found that there is slow progress in board diversity in Malaysia over five years from the year 2005 to 2009 and claimed there is the need for more efforts to encourage board diversity in Malaysia. 
MANAGEMENT SCIENCES

Vol. 11 , No. 3, 2021, E-ISSN: 2225-8329 @ 2021 HRMARS

\section{Gender Theory and Board Diversity}

There are several interrelated reasons for the effect of gender diversity and financial reporting quality. Previous literature has acknowledged that significant gender-based differences exist, for instance, in leadership styles, communicative skills, conservatism, risk averseness, and decision-making. Due to these differences and their potential implications for corporate governance, the issue of gender diversity has begun to receive increasing attention in the literature over the past few years. Several studies have recently focused on the effects that female directors may potentially have on the EM practices of a company. In this paper, we attempt to extend this literature by addressing the effects of female directors on financial reporting quality proxied by discretionary accruals.

Two theories suggest greater gender diversity may contribute to better board effectiveness: gender theory and agency theory. According to the gender theory perspective, Eagly et al., (1995) suggested that an individual's gender determines his or her behavior. It is suggested by the theory that men and women have normatively expected behavior and that individuals who use strategies that are aligned to their gender tend to be greater perceived by others (Eagly et al., 1995). For example, men are expected to be more assertive and aggressive than women (Terjesen et al., 2016). In addition, (Rosener, 1997) claimed that women are more flexible and able to manage ambiguous situations. These gender differences may be relevant factors that influence the effectiveness of the board of directors.

Meanwhile, from the agency theory perspective, Virtanen (2012) claimed that females are more likely to take active roles on boards of directors than men did. Likewise, Adams \& Ferreira (2009) asserted that female directors are more dynamic on corporate boards and have a better attendance record than male directors. Furthermore, the presence of female directors on corporate boards enhances their independence and improves their efficiency to improve firm performance and value (Abad et al., 2017; Carter et al., 2003; Terjesen et al., 2016)

It has been long acknowledged in cognitive psychology and management literature that significant gender differences exist e.g. in conservatism, risk averseness, and ethical behavior (Chen, Haiyang \& Volpe, 2002; Jianakoplos \& Bernasek, 1998; Byrnes et al., 1999; Schubert, 2006)

To address the above arguments, this study proposes the following hypotheses:

H1. There is a significant relationship between female directors on board and financial reporting quality.

H2. There is a significant relationship between independent female directors on board and financial reporting quality.

H3. There is a significant relationship between independent female directors on Audit Committee and financial reporting quality.

\section{Research Methodology}

This study examined the latest sample of construction companies listed on Bursa Malaysia throughout 2016 - 2020. The focus is construction companies as the firms are subject to special financial reporting standards in Malaysia for the calculation, MFRS 15. In addition, construction companies with unique features, provide greater opportunities for earnings management Wan Abdullah (2012). This selection criterion ensures that our sample consists of a sufficiently large and homogeneous sample. This study excludes firms with incomplete data. The final sample consists of 345 firm-year observations. Financial data are gathered 
MANAGEMENT SCIENCES

Vol. 11, No. 3, 2021, E-ISSN: 2225-8329 @ 2021 HRMARS

from the Data stream system and data on the board of directors are gathered from annual reports of each company that are available on the Bursa Malaysia website.

\section{Measurement for Dependent Variable: Accruals Earnings Management}

In order to examine the level of EM, this study employed a well-recognized EM model, Modified Jones Model by Dechow et al., (1995).

TACCit $=$ NIit - CFFOit (1)

NDACit $=\alpha i[1 /$ T Ait -1$]+\beta 1[(\triangle R E V i t-\triangle R E C i t) /$ TAit -1$]+\beta 2 P P E i t /$ TAit -1 (2)

TACCit $/$ T Ait $-1=\alpha i[1 /$ TAit -1$]+\beta 1[(\Delta R E V i t-\triangle R E C i t) /$ TAit -1$]+\beta 2 P$ PEit $/$ TAit $-1+$ cit

(3)

DACCit $=$ eit $=$ TACCitT Ait $-1-$ NDACit (4)

Where DACCit is the discretionary accruals in year $\mathrm{t}$, TACCit is the total accruals in year $\mathrm{t}$, NDACit is the non-discretionary accruals in year t, TAit-1 is the total assets in year $\mathrm{t}-1$, NIit is the net income in year t, CFFOit is the net cash flow from operations in year $\mathrm{t}$, cit is the error term in year $\mathrm{t}$, and $i$ is the individual firm in year $\mathrm{t}$. The coefficients in equation 2 for each year are applied in equation 3 for each company accordingly. DACC is the error term in equation 3.

\section{Measurement for Independent Variables}

There are some arguments on the positive association between board diversity with EM and in contrast other arguments on the negative association. The current study hypothesizes that the presence of female directors on the corporate board mitigates EM. The independent variables in this study consist of three main board gender characteristics including, female directors on board (BF), independent female director on board (BINDF), and female director on Audit Committee with expertise (ACEF). Therefore, three proxies are used to measure board gender diversity.

\section{Measurement for Control Variables}

To account for the potentially confounding effects of corporate governance characteristics and specific firm characteristics that may affect EM, this study includes control variables in the model. The control variables for corporate governance are board of directors' size (BSIZE), measured by the total number of board of directors, board independence (BIND) is measured by the number of independent directors on board, audit committee (AC) is measured by the number of Audit Committee on board, Audit Committee with expertise (ACE) is measured by the number of board of directors on Audit Committee with expertise in accounting and auditing. The firm characteristics control variables are types of auditor (BIG4), measured by dummy variable 1 if the auditor is from Big4 audit firm, otherwise 0 , firm size (FS), measured as the natural logarithm of total assets; firm leverage (DTE), calculated as total debts divided by total equity; firm profitability (ROE), measured by net income divided by total equity. Many of the previous studies have suggested that these corporate governance characteristics and firm-specific characteristics are useful in explaining EM behavior.

\section{Research Model}

To test the hypotheses of this study and estimate the effects of board gender diversity, and control variables on $E M$, the following panel regression model is employed:

$A E M=\alpha+\beta 1 B F+\beta 2 B I N D F+\beta 3 A C E F+\beta 4 B S I Z E+\beta 5 B I N D+\beta 6 A C+\beta 7 A C E+\beta 8 B I G 4+\beta 9 F S+$ $+\beta 10 D T E+\beta 11 R O E+e(1)$ 
MANAGEMENT SCIENCES

Vol. 11, No. 3, 2021, E-ISSN: 2225-8329 @ 2021 HRMARS

Where:

AEM is Accruals Earnings Management proxy by Discretionary Accruals figure; BF is the number of female directors on boards, BINDF is the number of female independence directors on boards, ACEF is the number of female directors with expertise on Audit Committee, BSIZE is the number of directors on boards; BIND is the number of Independence Directors on board, AC is the number of director on Audit Committee, ACE is the number of director on Audit Committee that has the expertise, BIG4 is the type of external auditor of the company, FS is the firm size measured by log Total Assets; DTE is debt to equity ratio proxy for debt covenant, ROE is a return on asset proxy for firm performance calculated by dividing net income with total equity. All the assumptions of regression analysis are met in this study.

Results and Discussion

Table 4.1: Descriptive Statistics

\begin{tabular}{lllllllllllll}
\hline & AEM & BF & $\begin{array}{c}\text { BIN } \\
\text { DF }\end{array}$ & $\begin{array}{c}\text { ACE } \\
\text { F }\end{array}$ & $\begin{array}{c}\text { BSIZ } \\
\text { E }\end{array}$ & $\begin{array}{c}\text { BIN } \\
\text { D }\end{array}$ & AC & ACE & BIG4 & FS & DTE & ROE \\
\hline Min & - & 0 & 0 & 0 & 4 & 0 & 2 & 0 & 0 & 9.206 & - & - \\
& 1.60 & & & & & & & & & & 19.37 & 3.33 \\
& 2 & & & & & & & & & & 0 & 7 \\
Max & 1.00 & 3 & 2 & 1 & 11 & 8 & 5 & 2 & 1 & 16.95 & 21.17 & 2.23 \\
& & & & & & & & & & 1 & 9 & 1 \\
Mean & - & 0.74 & 0.34 & 0.10 & 6.89 & 3.4 & 3.22 & 1.19 & 0.275 & 13.01 & 0.822 & - \\
& 0.23 & 5 & 4 & 4 & 5 & & 3 & 1 & & 9 & & 0.01 \\
& 6 & & & & & & & & & & & 2 \\
Std & 0.32 & 0.79 & 0.61 & 0.30 & 1.46 & 1.0 & 0.58 & 0.49 & 0.447 & 1.492 & 2.162 & 0.34 \\
Dev & 0 & 89 & 4 & 6 & 6 & 04 & 0 & 2 & & & & 1 \\
\hline
\end{tabular}

Note:

This table presents the descriptive statistics for a final sample of 345 firm-year observations. AEM is Accruals Earnings Management proxy by Discretionary Accruals figure; BF is the number of female directors on boards, BIF is the number of female Independence Director on boards, ACEF is the number of female directors with expertise on Audit Committee, BSIZE is the number of directors on boards; BIND is the number of Independence Directors on board, $A C$ is the number of director on Audit Committee, ACE is the number of director on Audit Committee that has the expertise, BIG4 is the type of external auditor of the company, FS is the firm size measured by log Total Assets; DTE is debt to equity ratio proxy for debt covenant, ROE is a return on asset proxy for firm performance calculated by dividing net income with total equity.

Tables 4.1 present descriptive statistics for all the variables used from the year 2016 - 2020. It includes EM measures, namely, Accruals Earnings Management (AEM) and the gender diversity of the board of directors in terms of female directors of board (BF), female independence board of directors (BINDF), and female directors on the Audit Committee with expertise (ACEF). The statistics also report the control variables for other corporate governance characteristics such as board size, board independence, Audit Committee expertise, auditors, and firms' characteristics, such as size, leverage, and performance. The mean value of AEM is -0.236 which implies that the majority of the firms manage their earnings using income decreasing accruals. These results indicate that Malaysian construction companies engaged in earnings management either through income-increasing earnings or 
income-decreasing earnings to hide their true financial performance. These results imply that accrual-based are large in magnitude and trends in some Malaysian companies, as some managers have motivations to manage corporate earnings upward and downward for purposes, such as managers' compensation or income tax reduction. The results obtained are consistent with the evidence of (Arun et al., 2015; Gull et al., 2018; Kyaw et al., 2015; Orazalin, 2020; Saona et al., 2019; Thiruvadi and Huang, 2011).

The results for board females $(\mathrm{BF})$ indicate that on average (mean value $=0.745$ ) at least every company has at least one female director on board. The range for female independent directors on board is from 0 to 2 directors only. Meanwhile, for female directors on Audit Committee with expertise, the range is between o to 1 director. The mean value is only 0.104 which indicates that only small number of companies that pose female director with expertise that sits on Audit Committee.

The results for other corporate governance characteristics indicate that the average number of directors on the board is 7, with a range from 4 to 11 directors. The average independent directors on the board have a mean value of 3.4, and it ranges from 0 to 8 directors. The minimum of 0 is consistent with the results obtained by Orazalin (2020) and Cigna and Meziou, (2017) that some companies do not maintain a minimum threshold of one-third of board members should be outside independent directors, which do not meet the requirements of code of corporate governance and listing requirements. In addition, the statistics for firm characteristics show that the mean value of BIG4 is 0.275 which indicates that only $27.50 \%$ of the companies employed Big Four auditors to audit their financial statements. The mean values for firm size, leverage and profitability are 13.019, 0.822 and 0.012 respectively. For the skewness and kurtosis, the values must be between -2 and 2 . All variables are within this range and considered as normal. 
Table 4.2: Pearson Correlation

\begin{tabular}{|c|c|c|c|c|c|c|c|c|c|c|c|c|}
\hline & AEM & $\mathrm{BF}$ & $\mathrm{BIF}$ & ACEF & $\begin{array}{c}\text { BSIZ } \\
\text { E }\end{array}$ & $\begin{array}{c}\text { BIN } \\
D\end{array}$ & $A C$ & ACE & BIG4 & FS & DTE & ROE \\
\hline $\mathrm{AE}$ & 1.00 & & & & & & & & & & & \\
\hline $\mathbf{M}$ & 0 & & & & & & & & & & & \\
\hline BF & $\begin{array}{l}- \\
0.04 \\
4\end{array}$ & 1.000 & & & & & & & & & & \\
\hline BIF & $\begin{array}{l}0.07 \\
3^{*}\end{array}$ & $\begin{array}{l}0.547 \\
* * *\end{array}$ & 1.000 & & & & & & & & & \\
\hline $\begin{array}{l}\text { ACE } \\
F\end{array}$ & $\begin{array}{l}0.02 \\
3\end{array}$ & $\begin{array}{l}0.311 \\
* * *\end{array}$ & $\begin{array}{l}0.550 \\
* * *\end{array}$ & $\begin{array}{l}1.000 \\
*\end{array}$ & & & & & & & & \\
\hline $\begin{array}{l}\text { BSI } \\
\text { ZE }\end{array}$ & $\begin{array}{l}0.09 \\
1^{* *}\end{array}$ & $\begin{array}{l}0.391 \\
* * *\end{array}$ & $\begin{array}{l}0.192 \\
* * *\end{array}$ & 0.083 & & & & & & & & \\
\hline $\begin{array}{l}\text { BIN } \\
\text { D }\end{array}$ & $\begin{array}{l}0.16 \\
4 * * *\end{array}$ & $\begin{array}{l}0.229 \\
* * *\end{array}$ & $\begin{array}{l}0.308 \\
* *\end{array}$ & $\begin{array}{l}0.025 \\
* *\end{array}$ & $\begin{array}{l}0.447 \\
* * *\end{array}$ & 1.000 & & & & & & \\
\hline$A C$ & $\begin{array}{l}0.15 \\
7 * * *\end{array}$ & $\begin{array}{l}0.092 \\
* *\end{array}$ & $\begin{array}{l}0.101 \\
*\end{array}$ & $\begin{array}{l}0.098 \\
* *\end{array}$ & $\begin{array}{l}0.25 \\
6\end{array}$ & $\begin{array}{l}- \\
0.007 \\
* * *\end{array}$ & $\begin{array}{l}1.00 \\
0\end{array}$ & & & & & \\
\hline ACE & $\begin{array}{l}0.06 \\
7\end{array}$ & $\begin{array}{l}- \\
0.060\end{array}$ & $\begin{array}{l}0.079 \\
*\end{array}$ & 0.137 & $\begin{array}{l}0.05 \\
6^{* *}\end{array}$ & $\begin{array}{l}- \\
0.125 \\
* * *\end{array}$ & $\begin{array}{l}- \\
0.00 \\
7 * *\end{array}$ & 1.000 & & & & \\
\hline $\begin{array}{l}\text { BIG } \\
4\end{array}$ & $\begin{array}{l}- \\
0.02 \\
9\end{array}$ & $\begin{array}{l}0.173 \\
* * *\end{array}$ & $\begin{array}{l}0.076 \\
* *\end{array}$ & $\begin{array}{l}- \\
0.019 \\
* * *\end{array}$ & $\begin{array}{l}0.155 \\
* * *\end{array}$ & $\begin{array}{l}0.129 \\
* *\end{array}$ & $\begin{array}{l}- \\
0.12 \\
5^{* *}\end{array}$ & $\begin{array}{l}0.090 \\
* *\end{array}$ & 1.000 & & & \\
\hline FS & $\begin{array}{l}0.14 \\
9 * * *\end{array}$ & $\begin{array}{l}0.270 \\
* * *\end{array}$ & $\begin{array}{l}0.273 \\
* * *\end{array}$ & 0.282 & $\begin{array}{l}0.35 \\
9 *\end{array}$ & $\begin{array}{l}0.043 \\
* * *\end{array}$ & $\begin{array}{l}0.12 \\
9\end{array}$ & $\begin{array}{l}0.140 \\
* *\end{array}$ & $\begin{array}{l}0.345 \\
* * *\end{array}$ & $\begin{array}{l}1.00 \\
0\end{array}$ & & \\
\hline DTE & $\begin{array}{l}0.11 \\
8 * *\end{array}$ & $\begin{array}{l}- \\
0.028\end{array}$ & 0.063 & $\begin{array}{l}0.051 \\
*\end{array}$ & $\begin{array}{l}0.07 \\
5\end{array}$ & $\begin{array}{l}0.062 \\
* * *\end{array}$ & $\begin{array}{l}0.04 \\
3\end{array}$ & 0.070 & $\begin{array}{l}0.169 \\
*\end{array}$ & $\begin{array}{l}0.24 \\
2^{*}\end{array}$ & 1.000 & \\
\hline RO & 0.06 & 0.042 & - & - & 0.05 & 0.002 & 0.06 & - & - & 0.06 & - & 1.00 \\
\hline$E$ & 8 & & 0.012 & 0.083 & 8 & & 2 & 0.085 & 0.076 & $0 * *$ & $\begin{array}{l}0.578 \\
* *\end{array}$ & 0 \\
\hline
\end{tabular}

\section{Note:}

This table shows the results for correlation analysis for a sample of 345 firm-year observations.

AEM is Accruals Earnings Management proxy by Discretionary Accruals figure; BF is the number of female directors on boards, BIF is the number of female Independence Director on boards, ACEF is the number of female directors with expertise on Audit Committee, BSIZE is the number of directors on boards; BIND is the number of Independence Directors on board, AC is the number of director on Audit Committee, ACE is the number of director on Audit Committee that has the expertise, BIG4 is the type of external auditor of the company, FS is the firm size measured by log Total Assets; DTE is debt to equity ratio proxy for debt covenant, ROE is a return on asset proxy for firm performance calculated by dividing net income with total equity.

***Significant at the $1 \%$ level, **Significant at the $5 \%$ level, *Significant at the $10 \%$ level 
MANAGEMENT SCIENCES

Vol. 11, No. 3, 2021, E-ISSN: 2225-8329 @ 2021 HRMARS

Table 4.2 presents the results of pair-wise Pearson correlation parameters with the t-statistic values for all the variables employed in this study. As can be seen in the table, the highest correlation estimate is between BIF and ACEF at 0.550. The reported coefficients between independent variables indicate that multicollinearity is not an issue in this study because according to Pallant (2007) multicollinearity issue is present in the regression analysis if the correlation coefficient between independent variables is above 0.700 . The Variance Inflation Factor (VIF) measures, as well as the correlations between the explanatory variables in the regression model, indicate the absence of multicollinearity that could challenge the inferences obtained from the regression specification.

Table 4.3: Regression results

\begin{tabular}{ccc}
\hline & AEM & t-Statistics \\
\hline Variables & & \\
Constant & $-3.087^{* * *}$ & \\
BF & $-0.133^{* *}$ & -1.933 \\
BINDF & 0.096 & 1.279 \\
ACEF & -0.032 & -0.470 \\
BSIZE & 0.027 & 0.421 \\
BIND & 0.062 & 0.949 \\
AC & $0.100^{*}$ & 1.750 \\
ACE & 0.047 & 0.872 \\
BIG4 & -0.065 & -1.113 \\
FS & 0.091 & 1.364 \\
DTE & $0.165^{* *}$ & 2.361 \\
ROE & $0.151^{* *}$ & 2.228 \\
& & \\
R-square & 0.089 & \\
Adjusted R-square & 0.059 & \\
F-statistics & 2.952 & \\
\hline
\end{tabular}

Note:

This table shows the model summary of each Earnings Management value for a sample of 345 firm-year observations.

$\mathrm{R}$-square is the regression coefficient determination.

Adjusted R-square is the adjusted regression coefficient determination.

F-statistics is the indication of how much variation is explained by the regression equation.

AEM is Accruals Earnings Management proxy by Discretionary Accruals figure; BF is the number of female directors on boards, BIF is the number of female Independence Director on boards, ACEF is the number of female directors with expertise on Audit Committee, BSIZE is the number of directors on boards; BIND is the number of Independence Directors on board, $A C$ is the number of director on Audit Committee, ACE is the number of director on Audit Committee that has the expertise, BIG4 is the type of external auditor of the company, FS is the firm size measured by log Total Assets; DTE is debt to equity ratio proxy for debt covenant, ROE is a return on asset proxy for firm performance calculated by dividing net income with total equity.

***Significant at the $1 \%$ level, ${ }^{* *}$ Significant at the $5 \%$ level, *Significant at the $10 \%$ level Table 4.3 presents the results of regression analysis between EM, gender variables, and all the control variables measured in this study from the year 2016 to 2020 . The results indicate 
MANAGEMENT SCIENCES

Vol. 11, No. 3, 2021, E-ISSN: 2225-8329 @ 2021 HRMARS

that AEM is negatively related to $\mathrm{BF}$ at a $5 \%$ significant level. The significant negative relationship between $\mathrm{AEM}$ and $\mathrm{BF}$ confirm $\mathrm{H1}$ and is consistent with the results obtained by Gull et al (2018); Triki Damak (2018); Orazalin (2020) The results, thus, suggest that having women directors on corporate boards helps to mitigate EM and improve financial reporting quality. The female director becomes one of the factors that help to mitigate EM in Malaysia through accruals EM. The results obtained in this study are consistent with the argument in the gender theory, women are more conservative and unbiased than men in making ethical decisions. The findings imply that the presence of female directors improves board monitoring as they constrain earnings management more than their male counterparts. The statistics show that there is a negative relationship between ACEF and EM, but it is insignificant. The weak relationship between female directors with expertise on Audit Committee and EM suggests that probably the number of female directors with expertise on board is too small to play their role in mitigating earnings management. Besides, there is no significant relationship between BINDF and EM indicates that independence female director on board has yet to achieve their effectiveness in mitigating earnings management. The results are in line with those found by Orazalin (2020); Mohammad et al (2018). Thus, H2 and H3 are not supported in this study.

For control variables, there is a negative relationship between AEM and BIG4, but it is not significant. The weak relationship suggests that this might be due to the percentage of companies that employ BIG4 auditors being too small, which is only $27.50 \%$ as stated in Table 4.1. However, firm leverage (DTE) and profitability (ROE) are found to have a significant positive relationship with $A E M$ at a $5 \%$ level. The results suggest that the larger the percentage of debt-to-equity ratio and return on equity of a firm, the more tendency the company to manage its earnings. This indicates that the higher the leverage and profitability of a company the higher the propensity to engage in earnings manipulation. The adjusted Rsquared and adjusted R-squared for this linear regression model are $8.9 \%$ and $5.9 \%$ respectively. The F-statistics values 2.952 and it is significant at a $1 \%$ level. The significant value of F-statistics means that the alternative hypotheses are compatible with observed data.

\section{Conclusion}

The main objective of this study is to determine the impact of gender on corporate boards, that is having women on board of directors and the financial reporting quality associated with it. Based on the results obtained, it is found that there is a significant negative relationship between female directors and the level of EM as a proxy of financial reporting quality. This suggests that having female directors on the corporate board is a good mechanism in mitigating EM in Malaysia. This study sheds further light on the importance of the presence of a female director on the corporate board may affect management decisions and financial reporting quality positively. Thus, this study is accepting the $\mathrm{H} 1$ hypothesis. Consistent with previous literature, this research contributes to the existing literature that women are more risk-averse, cautious, and ethical than men. The findings, therefore, suggest and shed further light on the importance of having women on corporate boards and the positive outcomes that are associated with it. Therefore, gender diversity on the board should be more strongly emphasized and their presence on the board may further enhance public confidence.

This study extends the corporate governance literature to the setting of the emerging market by highlighting Malaysia and investigates whether effective corporate governance 
MANAGEMENT SCIENCES

Vol. 11, No. 3, 2021, E-ISSN: 2225-8329 @ 2021 HRMARS

mechanisms in terms of board characteristics mitigate EM practices. The findings of this study provide input for regulators and policymakers such as Bursa Malaysia, Securities Commission Malaysia (SCM), and the Malaysian Institute of Corporate Governance (MICG) to revisit their policies and reforms to improve board gender diversity. It is recommended for the MICG to revise the Malaysian Code of Corporate Governance to enlighten public listed companies in Malaysia about the significant role of female directors on board and having at least one female director on the board. In addition, it is recommended to SCM to highlight the importance of having female directors on board in the listing requirements on Bursa Malaysia. Constant reviewing rules and regulations, as well as enforcement, are very important to ensure that good governance and quality as well as reliability of reported financial reporting in Malaysia.

This study includes several opportunities for future research, specifically with regards to different methodology, sample size, sample periods, or current regulations related to corporate governance. In extending the current research, the proxies for gender diversity can be extended using other variables such as dummy variables or percentages instead of the absolute number representing gender. Future studies may use other measures of earnings quality such as real earnings management, earnings persistence, earnings predictability, and conservatism. The findings of this research might not be generalizable to other developing countries which have different rules and regulatory structures. Therefore, future comparative research including other emerging markets would provide new insights on the effects of gender diversity and EM in different countries.

\section{Acknowledgement}

The authors are grateful to the anonymous reviewer and the editor, for their invaluable comments and suggestions and appreciate the comments made by the participants at the 4th iCARE2021. In addition, the authors acknowledge the financial support from the Faculty of Accountancy, Universiti Teknologi MARA, Perak Branch, Tapah Campus, Malaysia.

\section{References}

Abad, D., Lucas-Pérez, M. E., Minguez-Vera, A., \& Yagüe, J. (2017). Does gender diversity on corporate boards reduce information asymmetry in equity markets? $B R Q$ Business Research Quarterly, 20(3), 192-205. https://doi.org/10.1016/j.brq.2017.04.001

Adams, R. B., \& Ferreira, D. (2009). Women in the boardroom and their impact on governance and performance. Journal of Financial Economics, 94(2), 291-309. https://doi.org/10.1016/j.jfineco.2008.10.007

Al-Shaer, H., \& Zaman, M. (2016). Board gender diversity and sustainability reporting quality. Journal of Contemporary Accounting and Economics, 12(3), 210-222.

https://doi.org/10.1016/j.jcae.2016.09.001

Albawwat, I. E., \& Harasees, M. N. Al. (2019). Gender Attributes of Audit Committee Members and the Quality of Financial Reports. International Journal of Academic Research in Accounting, Finance and Management Sciences, 9(3), 24-37. https://doi.org/10.6007/ijarafms/v9-i3/6323

Arun, T. G., Almahrog, Y. E., \& Ali Aribi, Z. (2015). Female directors and earnings management: Evidence from UK companies. International Review of Financial Analysis, 39, 137-146. https://doi.org/10.1016/j.irfa.2015.03.002

Byrnes, J. P., Miller, D. C., \& Schafer, W. D. (1999). Gender differences in risk-taking: A meta- 
analysis. Psychological Bulletin, 125(3), 367-383. https://doi.org/10.1037/00332909.125.3.367

Carter, D., Simkins, B., \& Simpson, W. G. (2003). Corporate Governance, Board Diversity, and Firm Value. The Financial Review, 38(1), 33-53.

https://econpapers.repec.org/scripts/redir.pf?u=https\%3A\%2F\%2Fdoi.org\%2F10.1111 \%2F1540-6288.00034;h=repec:bla:finrev:v:38:y:2003:i:1:p:33-53

Chen, Haiyang \& Volpe, R. (2002). Gender differences in risk behaviour in financial decision making: An experimental analysis. Journal of Economic Psychology, 18(11), 605-628. https://doi.org/10.1016/S0167-4870(97)00026-3

Chen, H., Chen, J. Z., Lobo, G. J., \& Wang, Y. (2011). Effects of Audit Quality on Earnings Management and Cost of Equity Capital: Evidence from China. Contemporary Accounting Research, 28(3 (Fall 2011)), 892-925. https://doi.org/10.1111/j.19113846.2011.01088.x

Chi, C. W., Hung, K., Cheng, H. W., \& Lieu, P. T. (2015). Family firms and earnings management in Taiwan: Influence of corporate governance. International Review of Economics \& Finance, 36, 88-98. https://doi.org/10.1016/j.iref.2014.11.009

Cigna, G. P., \& Meziou, A. (2017). Corporate Governance in Transition Economies, Kazakhstan Country Report. European Bank for Reconstruction and Development, December.

Darmayanti, Y., \& Kassim, A. A. (2020). Female Directors Network, External Financing, and Earnings Quality Female Directors Network, External Financing, and Earnings Quality. Sciences, 1(3), 562-581. https://doi.org/10.6007/IJARAFMS

Dechow, P. M., Sloan, R. G., \& Sweeney, A. P. (1995). Detecting earnings management. Accounting Review, 70(2), 193-225. https://ssrn.com/abstract $=5520$

Eagly, A. H., Karau, S. J., \& Makhijani, M. G. (1995). Gender and the effectiveness of leaders. Psychological Bulletin, 117(1), 125-145.

Fama, E. F., \& Jensen, M. C. (1983). Separation of Ownership and Control Separation of Ownership and Control. Journal of Law and Economics, 26(2), 301-325.

Gull, A. A., Nekhili, M., Nagati, H., \& Chtioui, T. (2018). Beyond gender diversity: How specific attributes of female directors affect earnings management. British Accounting Review, 50(3), 255-274. https://doi.org/10.1016/j.bar.2017.09.001

Healy, P. M., \& Wahlen, J. M. (1999). A review of the earnings management literature and its implications for standard setting. Accounting Horizons, 13(4), 365-383. https://doi.org/10.2308/acch.1999.13.4.365

Hillman, A. J., \& Dalziel, T. (2003). Boards of directors and firm performance: Integrating agency and resource dependence perspectives. The Academy of Management Review, 28(3), 383-396. https://psycnet.apa.org/doi/10.2307/30040728

Jensen, M. C., \& Meckling, W. H. (2019). Theory of the firm: Managerial behavior, agency costs, and ownership structure. Corporate Governance: Values, Ethics and Leadership, 77-132. https://doi.org/10.2139/ssrn.94043

Jianakoplos, N. A., \& Bernasek, A. (1998). Are women more risk-averse? Economic Inquiry, 36(4), 620-630. https://doi.org/10.1111/j.1465-7295.1998.tb01740.x

Kalantonis, P., Schoina, S., \& Kallandranis, C. (2021). The impact of corporate governance on earnings management: Evidence from Greek listed firms. Corporate Ownership and Control, 18(2), 140-153. https://doi.org/10.22495/cocv18i2art11

Khalil, M., \& Ozkan, A. (2016). Board Independence, Audit Quality and Earnings Management: Evidence from Egypt. Journal of Emerging Market Finance, 15(1), 84-118. https://doi.org/10.1177\%2F0972652715623701 
MANAGEMENT SCIENCES

Vol. 11, No. 3, 2021, E-ISSN: 2225-8329 ๔ 2021 HRMARS

Krishnan, G. V., \& Parsons, L. M. (2008). Getting to the bottom line: An exploration of gender and earnings quality. Journal of Business Ethics, 78(1-2), 65-76.

https://doi.org/10.1007/s10551-006-9314-z

Kyaw, K., Olugbode, M., \& Petracci, B. (2015). Does gender-diverse board mean less earnings management? Finance Research Letters, 14, 135-141.

https://doi.org/10.1016/j.frl.2015.05.006

Liu, Y., Wei, Z., \& Xie, F. (2014). Do women directors improve firm performance in China? Journal of Corporate Finance, 28, 169-184. https://doi.org/10.1016/j.jcorpfin.2013.11.016

Orazalin, N. (2020). Board gender diversity, corporate governance, and earnings management: Evidence from an emerging market. Gender in Management, 35(1), 3760. https://doi.org/10.1108/GM-03-2018-0027

Peasnell, K. V., Pope, P. F., \& Young, S. (2005). Board Monitoring and Earnings Management: Do Outside Directors Influence Abnormal Accruals? Journal of Business Finance \& Accounting, 32(7/8), 1311-1346. https://doi.org/10.1111/j.0306-686X.2005.00630.x

Peni, E., \& Vähämaa, S. (2010). Female executives and earnings management. Managerial Finance, 36(7), 629-645. https://doi.org/10.1108/03074351011050343

Rosener, J. B. (1997). America's competitive secret: Women managers. Oxford University Press, New York, NY.

Saona, P., Muro, L., Martín, S. P., \& Baier-Fuentes, H. (2019). Board of directors' gender diversity and its impact on earnings management: An empirical analysis for select European firms. Technological and Economic Development of Economy, 25(4), 634-663. https://doi.org/10.3846/tede.2019.9381

Schipper, K. (1989). Earnings Management. Accounting Horizons, 3(4), 91-102.

Schubert, R. (2006). Analyzing and managing risks on the importance of gender differences in risk attitudes. Managerial Finance, 32(9), 706-715.

https://doi.org/10.1108/03074350610681925

Sun, L., \& Rath, S. (2008). Fundamental Determinants, Opportunistic Behavior, and Signaling Mechanism: An Integration of Earnings Management Perspectives. International Review of Business Research Papers, 4(4), 406-420.

Terjesen, S., Couto, E. B., \& Francisco, P. M. (2016). Does the presence of independent and female directors impact firm performance? A multi-country study of board diversity. Journal of Management and Governance, 20(3), 447-483. https://doi.org/10.1007/s10997-014-9307-8

Thiruvadi, S., \& Huang, H. W. (2011). Audit committee gender differences and earnings management. Gender in Management, 26(7), 483-498. https://doi.org/10.1108/17542411111175469

Damak, T. S. (2018). Gender diverse board and earnings management: evidence from French listed companies. Sustainability Accounting, Management and Policy Journal, 9(3), 289312. https://doi.org/10.1108/SAMPJ-08-2017-0088

Virtanen, A. (2012). Women on the boards of listed companies: Evidence from Finland. Journal of Management \& Government, 16(4), 571-593. https://doi.org/10.1007/s10997-010-9164-z

Abdullah, W. R. (2012). Earnings Management: Evidence Concerning Shariah-approved Companies in Malaysia [Lincoln University New Zealand]. https://researcharchive.lincoln.ac.nz/handle/10182/5483

Mohammad, W. M., Wasiuzzaman, S., Morsali, S. S., \& Zaini, R. M. (2018). The Effect of Audit 
INTERNATIONAL JOURNAL OF ACADEMIC RESEARCH IN ACCOUNTING, FINANCE AND MANAGEMENT SCIENCES

Vol. 11, No. 3, 2021, E-ISSN: 2225-8329 (C) 2021 HRMARS

Committee Characteristics on Financial Restatements in Malaysia. Journal of Asia-Pacific Business, 19(1), 4-22. https://doi.org/10.1080/10599231.2018.1419043

Zahra, S. A., \& Pearce, J. A. (1989). Boards of Directors and Corporate Financial Performance: A Review and Integrative Model. Journal of Management, 15(2), 291-334. https://doi.org/10.1177/014920638901500208

Zainal, D., Zulkifli, N., \& Saleh, Z. (2013). Corporate Board Diversity in Malaysia : A Longitudinal Analysis of Gender and Nationality Diversity. International Journal of Academic Research in Accounting, Finance and Management Sciences, 3(1), 136-148.

https://doi.org/10.6007/IJARAFMS 